\title{
EXPLORING PUBLIC PERCEPTION ABOUT COMEDY TV SHOWS OF PAKISTAN
}

\section{RIAZ M AND ALI S}

Department Of Communication Studies, Bahauddin Zakariya Univeristy, Multan, Pakistan

*Corresponding Author: E Mail: shahzadmasscomm@bzu.edu.pk

Received 24 ${ }^{\text {th }}$ Aug. 2019; Revised $8^{\text {th }}$ Oct. 2019; Accepted $10^{\text {th }}$ Dec. 2019; Available online $1^{\text {st }}$ June 2020 https://doi.org/10.31032/IJBPAS/2020/9.6.5124

\begin{abstract}
Private television channels in Pakistan have created a new practice of political satire shows in which they presented our politicians and politics in entertaining manners. These political comedy shows have a significant potential to form the opinions of the general public. This research article examined a comprehensive perception of the people about the leading comedy television shows of Pakistan. A survey of 774 respondents was administered in the Islamabad city by utilizing the probability sampling method. The Findings of the study revealed that the majority of people were convinced that comedy television shows are presenting a true picture of our society and politics. Most of the viewers were sure that these comedy shows have increased their trust in the political system and portrayed a positive image of democracy. Majority of the respondents agreed that caricatures of politicians in these comedies television shows are a significant source of entertainment for them. Most of the respondents agreed that these comedy television shows were spreading reliable information about politics and political procedures.
\end{abstract}

\section{Keywords: Public Perception, Political Satire, Comedy TV Shows, Political}

\section{Socialization, Political Awareness}

\section{INTRODUCTION}

Television has become a central medium of infotainment for last two decades in Pakistan. The emergence of private television channels has changed the taboos and conventional norms of the television industry. TV dramas were most popular 
when there was only PTV in Pakistan, but private television channels like, Geo, ARY, Dunya, Aaj, Express, Sama and other channels has changed the scenario. As we know that political talk shows are the most popular shows now a days. After the political talk shows, private television channels introduced comedy shows. Comedy shows like 'Mazak Raat', 'Khabardar', 'Khabarnaak' and 'Hasb e Haal' etc. has glued the public, instead of prime time dramas. Caricature, political satire, mockery and mimicry, used to find out irrationalities and insincerities, the variance between the portrayal of personalities, events or situations and their "actual" position [1].

Political satire shows produce feeling towards the capability and proficiency but that not inclines to the success of the political leader who is contesting the election. According to Hoon Lee [2], the efficiency of satirical programmes is almost equivalent to daily news and current affairs segments related to politics. He conducted a survey research with a sample of 700 respondents. He examined that most of the people have the tendency to share the contents of comedy TV shows on social media for interaction and exchange of ideas also. Prominent research scholars Philip Edwards, Dannagal, Paul R. Brewer [3] studied the impact and influence of comedy television shows on perceptions of a viewer who is an active participant of the political process. This particular influence has a significant association with voting behaviour. Political satirical television programmes formed an opinion in favour of some particular political parties and candidates.

Mass media and television have become an essential part of our daily life [4]. Viewers consumed mass media contents that shaped their particular perception. Politicians' rules and teachers determine still TV unconditionally has transformed the everyday routine and schedule of a common man. McHugh, Mary [5] investigated the impact and influence of the satirical programmes on Presidential election in the USA in 2008. A huge amount of youngsters were more attracted to political comedy programmes and the humorous messages of these shows. The research concluded that young audience framed the Presidential contenders as portrayed in comedy television shows. Recent studies indicate that individuals tend to watch what they desire to watch when the contents are confusing [6-8]. Hokenson [9] provides a very brief explanation of satire's goals: he says satire should not concern with real social responsibilities or issues in any open way.

STATEMENT OF THE PROBLEM 
This study investigated the public perception of the famous comedy television shows of contemporary electronic media and especially their role in political awareness and political socialization. This research also examined how people perceive the image, information and presentation of politics and political figures. Specifically, the study focused on the issue of how comedy television programmes affected the involvement of the people in political activities.

\section{OBJECTIVES OF THE STUDY}

Media and especially television is an essential part of our life. We formulate our opinion and perceive the depiction of the people and institutions, as the television and other media portray. We build our perception because of the media either it is print or electronic or comedy TV shows have an important role in this regard. The major objectives of this research are:

1. To examine the role of comedy TV programmes in political socialization and awareness among the people.

2. To find out, how comedy TV programmes affects the viewer's involvement in political progression.

3. To find out the role of comedy TV programmes in the voting behaviour of the viewers.

\section{LITERATURE REVIEW}

Parodies, dummies, mockeries and jokes are the main ingredients of these comedy shows. Besides the entertainment, these comedy shows have enough potential to influence and affect opinion formation. Renowned mass media scholars Baum [10], Pfau and Eveland Jr. [11] and Prior [12] studied the impacts and effects of comedy TV shows in-depth to examine its association with political awareness, political socialization, voting behaviour and perception especially.

The present study titled "Exploring public perception about comedy TV shows of Pakistan" was conducted with the main focus on public perception. Comedy TV satire has enough potential to impact on political attitude and behaviour of the general public. Kaid, Mckinney, and Tedesco [13] explored that information about politics and politicians is positively associated with the exposure to comedy and satire shows and it has also potential to enhance their awareness, political socialization effectiveness, especially in the case of youth. Some media scholars investigated media content practicing of satire regarding politics and politicians in "The Colbert Report and the effect or impacts of political philosophy on perceptions of Stephen Colbert" [14]. Cao and Brewer [15] explained this particular perception more and they pursued to recognize how satirical comedy shows can stimuli actively participate in politics. They 
established their hypothesis as exposure to comedy and satirical television shows escalate political awareness and active participation in the political process. Davis \& Owen [16] explained that most of the time comedy is used as a big tool for some particular aim and agenda. Maximum contents of the satirical programmes demolish and distort the image of a politician who is a contender also. Schutz [17] explored that satirical programmes of different television channels emphasized on the flaws, fumbles and faults of the candidates.

Cogan and Kelso [18] investigated how new trends became the essential part of satirical shows in the twentieth century when "stand-up comedian" type of programmes aired. Political socialization is another factor. Hollander [19] explained that Young viewers gain maximum political information about politicians, political parties and political movements by watching this type of satirical programmes. Experts of communication sciences explored majority of the young people are the viewers of satirical shows as compared to other television programmes.

Cooper \& Bates [20] and Young [21] elaborated that political satire programmes have a big influence on the people with less political interest, political awareness and information about politics. Audiences who were not enough interested in politics and political matters caused more consideration and they observed political comedy television shows more enjoyable and humorous [22]. On the other hand, people with less political awareness and information could not be capable to neglect the messages of satirical shows and interestingly they perceived as it was portrayed [23]. There were a large number of viewers who influenced by the messages of satirical television programmes and they made their mind accordingly. The most interesting thing was that all the viewers had less political information and awareness [24].

\section{METHODOLOGY}

In this research, the survey method has been adopted to get the required information from a large number of representatives of Islamabad. The researcher conducted a test study before data collection to check the validity and reliability of the questionnaire. A very comprehensive questionnaire was prepared to obtain the data and information of the respondents about TV Watching frequency and schedule, favourite comedy show, receiving information from the comedy TV show and content sharing of comedy TV shows. The key emphasized area of this study was the framing of the politicians. For this purpose, a total number of 774 
respondents as a sample of the general public was gathered throughout the Islamabad by utilizing the probability sampling method. Systematic random sampling method was adopted to draw the sample from the population.

Islamabad was distributed in three constituencies and 14 'Charges' by the Election Commission of Pakistan in 2018 general election. The researcher selected the Charge Number 1, Charge Number 3, Charge Number 5, Charge Number 7, Charge Number 9, Charge Number 11 and Charge Number 13 with the help of even and odd technique at the first stage. The very first voter list of selected seven charges was selected at the second stage.

The researcher had to select near about 55 respondents form every first male and female voter list from above mentioned seven charges (by using Morgan technique, male and female sample were same as 384 according to the statistics). At the third stage, the researcher started from serial number 1 and the next number was selected according to the sample interval. For example, the researcher had to select 55 male and 55 female respondents from the very first voter list of Charge Number 1(Block Code 501030101). The male registered voters were 298 and female registered voters were 224. After calculation researcher found that every $5^{\text {th }}$ male voter in the above-mentioned voter list will be included in the sample $(298 \div 5=59.6$, that is nearest number of 55$)$ and every $4^{\text {th }}$ female voter will be included in the total sample $(224 \div 4=56$, that is also nearest number to our sample). As calculation showed the variation from voter lists of Charge Number 5 and Charge Number 11, the researcher decided to take, $55,55,56,55,55,56$, and 55 respondents from above mentioned seven Charges as the sample of his research for sample strength. By using this technique for sample strength, the total sample increased as 387 and 387 instead of 384 . With the help of questionnaires, the data was gathered from the registered voters from different charges of Islamabad. According to the latest census, Islamabad is divided into 14 charges, and every charge is declared as "sub tehsil" by the Election Commission of Pakistan. The researcher personally visited house to house for collecting data from respondents and also hired the services of some research assistants. Five research assistants were appropriately trained in a preparation gathering to control all probable problems for ensuring of precision of the responses. The researcher always stayed in communication with the research assistants to solve any administrative, procedural or 
research related problems challenged by them.

When the data was gathered, the researcher coded all the answers from respondents into a Microsoft Excel sheet. The MS Excel coding sheet was evaluated in the IBM's SPSS 21 software for the production of findings to answer the research questions and assesses the research hypotheses. The results of the study have been displayed in the tabulated form. 387 Males and 387 Females, a total of 774, sample of respondents was taken from selected charges of the Federal Capital area.

\section{RESULTS AND FINDINGS}

Q. Comedy TV shows are presenting a true picture of our society?

As shown in the Table 1, (423) 54.7 percent respondents agreed that Comedy TV shows are presenting a true picture of our society followed by (168) 21.7 percent respondents, who strongly agreed. (102) 13.2 percent respondents were neutral, (65) 8.4 percent respondents disagreed and (16) 2.1 percent respondents strongly disagreed that Comedy TV shows are presenting a true picture of our society.

Q. Comedy TV shows are presenting a true picture of our politicians?

As shown in the Table 2, (308) 39.8 percent respondents agreed that Comedy TV shows are presenting a true picture of our politicians followed by (164) 21.2 percent respondents, who had a neutral opinion. (164) 21.2 percent respondents disagreed also, (103) 13.3 percent respondents strongly greed and (35) 4.5 percent respondents strongly disagreed that Comedy TV shows are presenting a true picture of our politicians.

Q. Comedy TV shows have increased your faith/trust in the political system of Pakistan.

As shown in the Table 3, (307) 39.7 percent respondents agreed that Comedy TV shows had increased their trust in the political system, followed by (273) 35.3 percent respondents, who disagreed. (120) 15.5 percent respondents were neutral, (37) 4.8 percent respondents strongly greed as well as (37) 4.8 percent respondents strongly disagreed that Comedy TV shows had increased their trust in the political system.

Q. Comedy TV shows convey to us that corruption and politics are part and parcel of each other?

As shown in the Table 4, (320) 41.3 percent respondents agreed that corruption and politics are part and parcel of each other, followed by (172) 22.2 percent respondents, who were neutral. (162) 20.9 percent respondents disagreed, (89) 11.5 percent respondents strongly agreed and (31) 4.0 percent respondents strongly 
disagreed that corruption and politics are part and parcel of each other.

Q. Caricatures of politicians in these comedy TV shows are a significant source of entertainment for the general public?

As shown in the Table 5, (469) 60.6 percent respondents agreed followed by (128) 16.5 percent respondents, who were neutral that caricatures of politicians in these comedy TV shows are a significant source of entertainment for the general public. (120) 15.5 percent respondents strongly agreed, (48) 6.2 percent respondents disagreed and (9) 1.2 percent respondents disagreed that caricatures of politicians in these comedy TV shows are a significant source of entertainment for the public.

Q. Comedy TV shows are presenting a positive image of democracy?

As shown in the Table 6, (354) 45.7 percent respondents disagreed followed by (215) 27.8 percent respondents, who agreed that comedy $\mathrm{TV}$ shows are portraying a positive image of democracy. (120) 15.5 percent respondents were neutral, (52) 6.7 percent respondents strongly disagreed and (33) 4.3 percent respondents strongly agreed that comedy TV shows are portraying a positive image of democracy.
Q. Comedy TV shows are spreading reliable information regarding politicians to the general public?

As shown in the Table 7 above, (346) 44.7 percent respondents agreed that Comedy TV shows are spreading the reliable political information for them followed by (165) 21.3 percent respondents, who were neutral. (138) 17.8 percent respondents disagreed, (105) 13.6 percent respondents strongly agreed and (20) 2.6 percent respondents strongly disagreed that Comedy TV shows are spreading the reliable political information for them.

Q. Comedy TV shows are helpful for providing information regarding political parties, politicians and election procedure?

As shown in the Table 8, (305) 39.4 percent respondents agreed that Comedy TV shows are helpful for providing information regarding political parties, politicians and election procedure for them followed by (195) 25.2 percent respondents, who disagreed. (171) 22.1 percent respondents were neutral, (75) 9.7 percent respondents strongly agreed and (28) 3.6 percent respondents strongly disagreed that Comedy TV shows are helpful for providing information regarding political parties, politicians and election procedure for them. 
Q. Voting trends among the public is increased due to these comedy TV shows?

As shown in the Table 9, (251) 32.4 percent respondents disagreed, followed by (229) 29.6 percent respondents, who agreed that voting trend is increased due to these comedy TV shows. (171) 22.1 percent respondents were neutral, (62) 8.0 percent respondents strongly agreed and (61) 7.9 percent respondents strongly disagreed that voting trend is increased due to these comedy TV shows.

Q. Comedy TV shows are playing a vital role in the favour of continuity of the democratic process?

As shown in the Table 10, (399) 51.6 percent respondents agreed, followed by (182) 23.5 percent respondents, who disagreed that comedy TV shows are playing a vital role in the favour of continuity of the democratic process. (88) 11.4 percent respondents were neutral, (53) 6.8 percent respondents strongly agreed and (52) 6.7 percent respondents strongly disagreed that comedy $\mathrm{TV}$ shows are playing a vital role in the favour of continuity of the democratic process.

Q. Satirical image of politicians presented by comedy TV shows is negatively affecting their political image? As shown in the Table 11, (349) 45.1 percent respondents disagreed, followed by
(145) 18.7 percent respondents, who were neutral that satirical image of politicians presented by comedy TV shows is negatively affecting their political image. (136) 17.6 percent respondents agreed, (107) 13.8 percent respondents strongly disagreed and (37) 4.8 percent respondents strongly agreed that satirical image of politicians presented by comedy TV shows is negatively affecting their political image.

Q. Satirical name-calling for many politicians, used in comedy $\mathrm{TV}$ shows is warmly accepted among the people?

As shown in the Table 12, (392) 50.6 percent respondents agreed followed by (254) 32.8 percent respondents, who strongly agreed that satirical name-calling for many politicians, used in these comedy TV shows, is warmly accepted among the people. (64) 8.3 percent respondents disagreed, (46) 5.9 percent respondents were neutral and (18) 2.3 percent respondents strongly disagreed that satirical name-calling for many politicians, used in these comedy TV shows, is warmly accepted among the people.

Q. The political parties/politicians use this satirical name-calling as a tool to defame their opposite political parties/politicians?

As shown in the Table 13, (278) 35.9 percent respondents agreed followed by (257) 35.9 percent respondents, who 
disagreed that political parties/politicians use this satirical name-calling as a tool to defame their opposite political parties/politicians. (110) 14.2 percent respondents were neutral, (65) 8.4 percent respondents strongly agreed and (64) 8.3 percent respondents strongly disagreed that political parties/politicians use this satirical name-calling as a tool to defame their opposite political parties/politicians.

Table 1: True Picture of Society

\begin{tabular}{|c|c|c|c|c|c|}
\hline & Frequency & Percent & Valid Percent & Cumulative Percent \\
\hline \multirow{4}{*}{ Strongly Agree } & 168 & 21.7 & 21.7 & 21.7 \\
\cline { 2 - 6 } & Agree & 423 & 54.7 & 54.7 & 76.4 \\
\cline { 2 - 6 } & Neutral & 102 & 13.2 & 13.2 & 89.5 \\
\cline { 2 - 6 } & Disagree & 65 & 8.4 & 8.4 & 97.9 \\
\cline { 2 - 6 } & Strongly Disagree & 16 & 2.1 & 2.1 & 100.0 \\
\cline { 2 - 6 } & Total & 774 & 100.0 & 100.0 & \\
\hline
\end{tabular}

Table 2: True Picture of Politicians

\begin{tabular}{|c|c|c|c|c|}
\hline & Frequency & Percent & Valid Percent & Cumulative Percent \\
\hline Strongly Agree & 103 & 13.3 & 13.3 & 13.3 \\
\hline Agree & 308 & 39.8 & 39.8 & 53.1 \\
\hline Neutral & 164 & 21.2 & 21.2 & 74.3 \\
\hline Disagree & 164 & 21.2 & 21.2 & 95.5 \\
\hline Strongly Disagree & 35 & 4.5 & 4.5 & 100.0 \\
\hline Total & 774 & 100.0 & 100.0 & \\
\hline
\end{tabular}

Table 3: Increased Trust in Political System

\begin{tabular}{|c|c|c|c|c|}
\hline & Frequency & Percent & Valid Percent & Cumulative Percent \\
\hline Strongly Agree & 37 & 4.8 & 4.8 & 4.8 \\
\hline Agree & 307 & 39.7 & 39.7 & 44.4 \\
\hline Neutral & 120 & 15.5 & 15.5 & 59.9 \\
\hline Disagree & 273 & 35.3 & 35.3 & 95.2 \\
\hline Strongly Disagree & 37 & 4.8 & 4.8 & 100.0 \\
\hline Total & 774 & 100.0 & 100.0 & \\
\hline
\end{tabular}

Table 4: Corruption and Politics are Part and Parcel

\begin{tabular}{|c|c|c|c|c|c|c|}
\hline \multicolumn{7}{c|}{ Table 4: Corruption and Politics are Part and Parcel } \\
\hline Strongly Agree & \multicolumn{2}{|c|}{ Frequency } & Percent & Valid Percent & Cumulative Percent \\
\hline Agree & 89 & 11.5 & 11.5 & $\mathbf{1 1 . 5}$ \\
\hline Neutral & 320 & 41.3 & 41.3 & $\mathbf{5 2 . 8}$ \\
\hline Disagree & 172 & 22.2 & 22.2 & $\mathbf{7 5 . 1}$ \\
\hline Strongly Disagree & 162 & 20.9 & 20.9 & $\mathbf{9 6 . 0}$ \\
\hline Total & 31 & 4.0 & 4.0 & \\
\hline
\end{tabular}

Table 5: Caricatures are Significant Source of Entertainment

\begin{tabular}{|l} 
Table 5: Caricatures are Significant Source of Entertainment \\
\begin{tabular}{|c|c|c|c|c|c|}
\hline & Frequency & Percent & Valid Percent & Cumulative Percent \\
\hline \multirow{4}{*}{ Strongly Agree } & 120 & 15.5 & 15.5 & 15.5 \\
\cline { 2 - 6 } & Agree & 469 & 60.6 & 60.6 & 76.1 \\
\cline { 2 - 7 } & Neutral & 128 & 16.5 & 16.5 & 92.6 \\
\cline { 2 - 7 } & Disagree & 48 & 6.2 & 6.2 & 98.8 \\
\cline { 2 - 7 } & Strongly Disagree & 9 & 1.2 & 1.2 & 100.0 \\
\cline { 2 - 7 } & Total & 774 & 100.0 & 100.0 & \\
\end{tabular}
\end{tabular}

Table 6: Positive Image of Democracy

\begin{tabular}{|c|c|c|c|c|c|}
\hline & Frequency & Percent & Valid Percent & Cumulative Percent \\
\hline \multirow{4}{*}{ Strongly Agree } & 33 & 4.3 & 4.3 & 4.3 \\
\cline { 2 - 7 } & Agree & 215 & 27.8 & 27.8 & 32.0 \\
\cline { 2 - 7 } & Neutral & 120 & 15.5 & 15.5 & 47.5 \\
\cline { 2 - 7 } & Disagree & 354 & 45.7 & 45.7 & 93.3 \\
\cline { 2 - 7 } & Strongly Disagree & 52 & 6.7 & $\mathbf{6 . 7}$ & 100.0 \\
\cline { 2 - 7 } & Total & 774 & 100.0 & 100.0 & \\
\end{tabular}


Table 7: Reliable Information

\begin{tabular}{|c|c|c|c|c|c|}
\hline & Frequency & Percent & Valid Percent & Cumulative Percent \\
\hline \multirow{4}{*}{ Strongly Agree } & 105 & 13.6 & 13.6 & 13.6 \\
\cline { 2 - 6 } & Agree & 346 & 44.7 & 44.7 & 58.3 \\
\cline { 2 - 6 } & Neutral & 165 & 21.3 & 21.3 & 79.6 \\
\cline { 2 - 6 } & Disagree & 138 & 17.8 & 17.8 & 97.4 \\
\cline { 2 - 6 } & Strongly Disagree & 20 & 2.6 & 2.6 & 100.0 \\
\cline { 2 - 6 } & Total & 774 & 100.0 & 100.0 & \\
\hline
\end{tabular}

Table 8: Helpful for Information

\begin{tabular}{|c|c|c|c|c|c|}
\hline \multicolumn{2}{|c|}{} & Frequency & Percent & Valid Percent & Cumulative Percent \\
\hline \multirow{4}{*}{ Strongly Agree } & 75 & 9.7 & 9.7 & 9.7 \\
\cline { 2 - 6 } & Agree & 305 & 39.4 & 39.4 & 49.1 \\
\cline { 2 - 6 } & Neutral & 171 & 22.1 & 22.1 & 71.2 \\
\cline { 2 - 6 } & Disagree & 195 & 25.2 & 25.2 & 96.4 \\
\cline { 2 - 6 } & Strongly Disagree & 28 & 3.6 & 3.6 & 100.0 \\
\hline
\end{tabular}

Table 9: Voting Trend is increased

\begin{tabular}{|c|c|c|c|c|c|}
\hline \multicolumn{2}{|c|}{} & Frequency & Percent & Valid Percent & Cumulative Percent \\
\hline \multirow{4}{*}{ Strongly Agree } & 62 & $\mathbf{8 . 0}$ & $\mathbf{8 . 0}$ & $\mathbf{8 . 0}$ \\
\cline { 2 - 6 } & Agree & $\mathbf{2 2 9}$ & $\mathbf{2 9 . 6}$ & $\mathbf{2 9 . 6}$ & 37.6 \\
\cline { 2 - 6 } & Neutral & 171 & $\mathbf{2 2 . 1}$ & $\mathbf{2 2 . 1}$ & $\mathbf{5 9 . 7}$ \\
\cline { 2 - 6 } & Disagree & $\mathbf{2 5 1}$ & $\mathbf{3 2 . 4}$ & $\mathbf{3 2 . 4}$ & $\mathbf{9 2 . 1}$ \\
\cline { 2 - 6 } & Strongly Disagree & $\mathbf{6 1}$ & $\mathbf{7 . 9}$ & $\mathbf{7 . 9}$ & $\mathbf{1 0 0 . 0}$ \\
\cline { 2 - 6 } & Total & $\mathbf{7 7 4}$ & $\mathbf{1 0 0 . 0}$ & $\mathbf{1 0 0 . 0}$ & \\
\hline
\end{tabular}

Table 10: Continuity of Democratic Process

\begin{tabular}{|c|c|c|c|c|c|}
\hline \multicolumn{2}{|c|}{} & Frequency & Percent & Valid Percent & Cumulative Percent \\
\hline \multirow{4}{*}{ Strongly Agree } & 53 & 6.8 & 6.8 & 6.8 \\
\cline { 2 - 6 } & Agree & 399 & 51.6 & 51.6 & 58.4 \\
\cline { 2 - 6 } & Neutral & 88 & 11.4 & 11.4 & 69.8 \\
\cline { 2 - 6 } & Disagree & 182 & 23.5 & 23.5 & 93.3 \\
\cline { 2 - 6 } & Strongly Disagree & 52 & 6.7 & 6.7 & 100.0 \\
\cline { 2 - 6 } & Total & 774 & 100.0 & 100.0 & \\
\hline
\end{tabular}

Table 11: Effects of Satirical Image

\begin{tabular}{|c|c|c|c|c|c|}
\hline & Frequency & Percent & Valid Percent & Cumulative Percent \\
\hline \multirow{4}{*}{ Strongly Agree } & 37 & 4.8 & 4.8 & 4.8 \\
\cline { 2 - 6 } & Agree & 136 & 17.6 & 17.6 & 22.4 \\
\cline { 2 - 6 } & Neutral & 145 & 18.7 & 18.7 & 41.1 \\
\cline { 2 - 6 } & Disagree & 349 & 45.1 & 45.1 & $\mathbf{8 6 . 2}$ \\
\cline { 2 - 6 } & Strongly Disagree & 107 & 13.8 & 13.8 & 100.0 \\
\cline { 2 - 6 } & Total & 774 & 100.0 & 100.0 & \\
\hline
\end{tabular}

Table 12: Name calling warmly accepted

\begin{tabular}{|c|c|c|c|c|c|}
\hline \multicolumn{1}{|c|}{} & Frequency & Percent & Valid Percent & Cumulative Percent \\
\hline \multirow{4}{*}{ Strongly Agree } & 254 & 32.8 & 32.8 & 32.8 \\
\cline { 2 - 6 } & Agree & 392 & 50.6 & 50.6 & 83.5 \\
\cline { 2 - 6 } & Neutral & 46 & 5.9 & 5.9 & 89.4 \\
\cline { 2 - 6 } & Disagree & 64 & 8.3 & 8.3 & 97.7 \\
\cline { 2 - 6 } & Strongly Disagree & 18 & 2.3 & 2.3 & 100.0 \\
\cline { 2 - 6 } & Total & 774 & 100.0 & 100.0 & \\
\hline
\end{tabular}

Table 13: Tool to Defame

\begin{tabular}{|c|c|c|c|c|c|}
\hline \multicolumn{2}{|c|}{} & Frequency & Percent & Valid Percent & Cumulative Percent \\
\hline \multirow{4}{*}{ Strongly Agree } & 65 & 8.4 & 8.4 & 8.4 \\
\cline { 2 - 6 } & Agree & 278 & 35.9 & 35.9 & 44.3 \\
\cline { 2 - 6 } & Neutral & 110 & 14.2 & 14.2 & 58.5 \\
\cline { 2 - 6 } & Disagree & 257 & 33.2 & 33.2 & 91.7 \\
\cline { 2 - 6 } & Strongly Disagree & 64 & 8.3 & 8.3 & 100.0 \\
\cline { 2 - 6 } & Total & 774 & 100.0 & 100.0 & \\
\hline
\end{tabular}




\section{CONCLUSION}

This Research pursued to explore the public perception about comedy shows of Pakistan. The researcher examined that comedy TV shows have substantial potential and effects that can mold and shape the opinions of the viewers. Findings of the study also cleared that there is a vital correlation between political socialization and exposure to comedy TV shows.

A large number of respondents were convinced that comedy $\mathrm{TV}$ shows are presenting a true picture of our society as well as our politicians. Near about forty percent respondents were agreed that their trust in the political system is increased because of these comedy TV shows. Majority of the respondents believed that our politicians are responsible for bad governance and political instability in our country. According to a significant majority of the respondents, corruption and politics are part and parcel of each other. Majority of the respondents were convinced that caricatures of the comedy TV shows are a big source of entertainment for them.

More than forty seven percent respondents were claimed that comedy shows are not portraying a positive image of democracy. The results of this research show that a large number of respondents were agreed that comedy shows are helpful for providing reliable political information.
Most of the people convinced that satirical name-calling for many politicians, used in comedy TV shows, is warmly accepted among the people. A large number of registered voters were sure that these comedy TV shows are playing a vital role in the favour of continuity of the democratic process. Different studies had analyzed the correlation of comedy TV shows and political socialization among the target audience. The people who were using satirical programmes to obtain political knowledge and awareness that influenced their political effectiveness, ability, faith and voting attitude. The findings of this research also indicated that most of the respondents negated that satirical image of politicians presented by comedy TV shows is negatively affecting their political image. Majority of respondents were sure that political parties and politicians used that satirical namecalling as a tool to defame their opposite political parties and politicians.

The results of the research undoubtedly confirmed that comedy TV shows are playing an important and crucial role in the process of opinion formation and perception formation. These comedy shows had enough potential to mould and shape the opinion of the general public. Findings of the research expediently recommended the cultivation theory, that TV is cultivating 
some specific concepts, knowledge, and culture about the politicians and moreover portraying them in some particular frames. According to the findings, political awareness, political socialization and voting trends are interconnected with the watching of these comedy TV shows. Most of the respondents claimed that comedy TV shows are a significant source of entertainment as well as political awareness and political knowledge about the election process, political parties and politicians.

\section{REFERENCES}

[1] Gray J., Jones J.P. and Thompson E. "Satire and the comedy in the post network era." NYU Press, New York 1.1 (2009): 3-36.

[2] Hoon L. "Communication Mediation Model of Late-Night Comedy: An Examination of the Mediating Role of Structural Features of Interpersonal Talk between Late-Night Comedy Viewing and Political Participation." Mass Communication and Society 15.5 (2012): 647-671

[3] Jones P.E., Young D.G., and Brewer P.R. "The Effects of Political Satire on Perceptions of Candidate Viability and Electability: An Ecologically Valid Experimental Approach.” Atlantic
Journal of Communication 24.3 (2016): 172-184

[4] Curran, J. "Media and Power." New York: Routledge, London 1.1 (2002): 7

[5] McHugh M. "Live from New York: The impact of Saturday Night Live and late night talk shows on the 2008 Presidential Election Race" $67^{\text {th }} \quad$ Annual National Conference of the Midwest Political Science Association The Palmer House Hilton, Chicago (2009).

[6] Kunda Z. "The Case for Motivated Reasoning." Psychological Bulletin 108.3 (1990): 480-498.

[7] Balcetis E. and David D. "See What You Want to See: Motivational Influences on Visual Perception." Journal of Personality and Social Psychology 91.4 (2006): 612-625.

[8] Long G. and Toppino T. "Enduring Interest in Perceptual Ambiguity: Alternating Views of Reversible Figures." Psychological Bulletin 130.5 (2004): 748-768.

[9] Hokenson J.W. "The Idea of Comedy: History, Theory, Critique." Rosemont Publishing \& Printing Corporation. Cranbury, NJ. 1.1 (2006): 28 
[10] Baum Matthew A. "Soft News and Political Knowledge: Evidence of Absence or Absence of Evidence?" Political Communication 20.2 (2003): 173190.

[11] Pfau M, Eveland Jr. W. P. "Influence of traditional and non-traditional news media in the 1992 election campaign." Western Journal of Communication 60.3 (2009): 214-232.

[12] Prior M. "Any Good News in Soft News? The Impact of Soft News Preference on Political Knowledge.” Political Communication 20.2 (2003): 149171.

[13] Kaid L.L., Mitchell S. McKinney M.S., John C. and Tedesco J.C. "Introduction: Political Information Efficacy and Young Voters." American Behavioral Scientist 50.9 (2007): 1093-1111.

[14] LaMarre H.L., Landreville K.D. and Beam M.A. "The Irony of Satire Political Ideology and the Motivation to See What You Want to See in The Colbert Report." International Journal of Press/Politics 14.2 (2009): 143145.
[15] Cao X, and Brewer P.R. "Political Comedy Shows and Public Participation in Politics." International Journal of Public Opinion Research, 20(1) (2008): 90-99.

[16] Davis R., and Owen D. New media and American politics. Newyork: Oxford University Press, 2008.

[17] Schutz C.E. "Political Humor: From Aristophanes to Sam Ervin." Fairleigh Dickinson University Press 1.1 (1977).

[18] Kelso T. and Cogan B. "Encyclopedia of Politics, the Media, and Popular Culture." Greenwood 1.1 (2009).

[19] Hollander B.A. (2005). "Late night learning: Do entertainment programmes increase political campaign knowledge for young viewers?" Journal of Broadcasting \& Electronic Media 49.4 (2009): 402-415.

[20] Cooper, C.A., \& Bates, M. (2003). I learned it from Jay Leno: Entertainment media in the 2000 election. Paper presented at the Annual Meeting of the North Carolina Political Science Association. Elton, NC. 
[21] Young, D.G. (2004). Late night comedy in election 2000: Its influence on candidate trait ratings and the moderating effects of political knowledge. Journal of Broadcasting and Media, 48, 2-22.

[22] West, D.M., \& Orman, J.M. (2003). Celebrity Politics. Prentice Hall.

[23] Zaller, J. (1992). The nature and origins of mass opinion. Cambridge: Cambridge University Press.

[24] Popkin, S.L. (1991). The reasoning voter: Communication and persuasion in presidential campaigns. Chicago: University of Chicago Press. 